\title{
Urgensi Inklusifitas Pelaksanaan Dakwah di Tengah Problematika Sosial
}

\author{
Anja Kusuma Atmaja1, Alfiana Yuniar Rahmawati ${ }^{2}$ \\ Fakultas Dakwah dan Komunikasi \\ Universitas Islam Negeri Sunan Kalijaga Yogyakarta
}

Korespodensi dengan Penulis:

Anja Kusuma Atmaja: Telp: 085269293992

E-mail: anjakusumafirst02@gmail.com

Keywords:
Inclusiveness,
Da'wah, Social
Problems

Kata kunci:

Inklusifitas,

Dakwah,

Problematika

Sosial

\begin{abstract}
The social problems that occur in society are certainly so complex if they have to be addressed one by one. A fact and reality that exist in everyday life are things that are an integral part of that situation. In digesting and seeking solutions to these social problems, as a Muslim everyone is required to be a solution in solving problems that exist and occur in social life itself. This study aims to describe in general the social problems that occur in people's lives by using the dakwah approach to solve them and to examine the problems using the library research method. The expected result of this research is to provide a general understanding to the public and readers in particular in order to interpret the importance of appreciating and accepting other people's opinions so that later the inclusiveness of society through da'wah can be a concept for solving these social problems.
\end{abstract}

\begin{abstract}
Abstrak
Problematika sosial yang terjadi di masyarakat tentu begitu kompleks jika harus diuraikan satu-persatu. Sebuah fakta dan realitas yang ada dalam kehidupan sehari-hari merupakan hal-hal yang menjadi bagian utuh dari keadaan itu. Dalam mencerna dan mencari penyelesaian problematika sosial tersebut, sebagai seorang Muslim semua orang dituntut untuk menjadi solusi dalam menyelesaikan permasalahan yang ada dan terjadi di dalam kehidupan sosial itu sendiri. Penelitian ini bertujuan untuk menguraikan secara umum problematika sosial yang terjadi dalam kehidupan masyarakat dengan menggunakan pendekatan dakwah guna menyelesaikannya serta menelaah persmasalahan dengan metode library research. Hasil yang diharapkan dari penelitan ini adalah memberikan pemahaman yang umum kepada masyarakat dan pembaca secara khusus agar memaknai pentingnya menghargai dan menerima apa yang menjadi pendapat orang lain sehingga nantinya inklusifitas masyarakat melalui dakwah bisa menjadi konsep penyelesaian problematika sosial tersebut.
\end{abstract}




\section{PENDAHULUAN}

Dakwah dalam banyak pengertiannya adalah apa yang dijalankan oleh Nabi dan Rasul terdahulu sebelum ditutup oleh Rasul terakhir yang diutus Allah SWT kepada umat manusia. Namun secara konteks, cara dan metode dakwah tentu berbeda dari zaman ke zaman, tetapi esensi dakwah ialah tetap mengajak manusia termasuk semua makhluk yang diciptakan oleh Allah SWT untuk menjadi insan yang berbakti kepada-Nya. Berserah diri, menjalankan perintah-Nya serta menjauhi larangan-Nya. Dakwah juga merupakan usaha membuka konfrontasi atau pertentangan keyakinan di tengah kehidupan manusia, memberikan dan membuka kemungkinan bagi kemanusiaan untuk menetapkan pilihannya sendiri yang ia yakini sebagai sebuah kebenaran yang haq. Dakwah Islam tentu saja dakwah yang merujuk kepada standar dan nilai-nilai kemanusiaan dalam tingkah laku pribadi-pribadi di dalam hubungan antar manusia dan sikap perilaku antar manusia. ${ }^{1}$

Selanjutnya, banyak tokoh yang mengemukakan makna dakwah Islam. Menurut Syekh Ali Mahfudz, Dakwah ialah kegiatan menyeru manusia agar melakukan kebaikan serta mengikuti ajaran yang benar, mengajak pada perbuatan-perbuatan baik, dan mencegah manusia lain dari melaksanakan kemungkaran demi menggapai kebahagiaan di dunia akhirat. ${ }^{2}$ Beberapa pengertian di atas sebetulnya lebih banyak menekankan pada rasa kemanusiaan yang mendalam. Bahwa mengajak orang kepada jalan dakwah merupakan suatu hal yang penting untuk dilakukan. Tetapi mengabaikan nilai-nilai kemanusiaan justru menjadikan arti dakwah itu sendiri menjadi sempit dan jauh dari kenyamanan dan nilai-nilai dakwah yang sebenarnya dibutuhkan.

Peranan dakwah dalam kehidupan masyarakat. Dakwah juga memiliki peranan penting dalam menyelesaikan persoalan sosial di masyarakat. Fungsi dakwah dan peranannya, tidak lain adalah memberikan jalan keluar yang benar dan tepat kepada umat manusia dari berbagai macam situasi yang serba kelam (darkness) menuju situasi yang terang (brightness). Watak dasar dakwah adalah mengubah (bersifat transformatif), ke arah yang lebih baik. Namun di lain sisi dakwah juga mempertahankan prinsip-prinsip ajaran atau nilai-nilai fundamental, yang di yakini kebenarannya, yang menjadi jati diri. ${ }^{3}$

Untuk itulah mengapa inklusifitas dalam pelaksanaan dakwah, penulis kira dibutuhkan untuk kembali disyi'arkan, diterangkan dan dipaparkan dengan metode yang tepat guna

\footnotetext{
1 Sulthon Muhammad, Desain Ilmu Dakwah, Jakarta: Pustaka Pelajar, 2003, hal. 8.

2 Rini Fitria dan Rafinita Aditia, Prospek dan Tantangan Dakwah Bil Qalam sebagai Metode Komunikasi, Jurnal Ilmiah Syi' ar Vol. 19 No. 02, 2019, hal. 226.

${ }^{3}$ Rahmat Ramdhani, Dakwah dan Pemberdayaan Masyarakat Berbasis Agama, Jurnal Syi' ar Vol. 18 No. 2 Juli-Desember 2018, hal. 8.
} 
menjawab dan menyelesaikan persoalan sosial di masyarakat kemudian merujuk pada situasi dan konteks yang kekinian.

Fokus penelitian dalam artikel ini ialah urgensi inklusifitas dalam pelaksanaan dakwah untuk menyikapi problematika sosial yang terjadi di masyarakat. Pertanyaan yang penulis akan jawab dalam bagaimana problematika sosial yang terjadi di masyarakat masa kini dan bagaimana inklusifitas dalam pelaksanaan dakwah Islam. Penulis akan menguraikan pembahasan dengan merujuk pada teori-teori yang berkenaan dengan persoalan yang telah penulis uraikan di atas. Beberapa penelitian terkait inklusifitas dakwah juga telah penulis tampilkan di dalam pembahasan yang penulis selaraskan dengan apa yang menjadi tujuan dan novelty dari penulisan artikel ini.

\section{METODE}

Metode yang digunakan dalam penelitian ini adalah metode deskriptif kualitatif. Metode penelitian deskriptif kualitatif adalah metode pengolahan data dengan cara menganalisa faktorfaktor yang berkaitan dengan objek penelitian dengan penyajian data secara lebih mendalam terhadap objek penelitian. Format deskriptif kualitatif bertujuan untuk menggambarkan, meringkas berbagai kondisi, situasi, atau fenomena realitas sosial dalam masyarakat yang menjadi objek penelitian dan berupaya menarik realitas itu ke permukaan sebagai suatu ciri, karakter, sifat, model, tanda, atau gambaran tentang kondisi, situasi, ataupun fenomena tertentu.

Rancangan penelitan ini dipilih karena melalui penelitian ini dapat diperoleh gambaran suatu kelompok manusia dalam mencapai tujuan dakwah seperti anjuran Rosululah SAW yang dikontekstualisasikan pada masa sekarang. Dalam memperoleh data yang sebanyakbanyaknya, peneliti mengumpulkan data melalui pengamatan atau observasi maupun studi dokumentasi, kemudian dilakukan analisis deskriptif untuk menentukan fokus penelitian.

Analisis data dimulai dengan meneliti status kelompok manusia, suatu set kondisi, serta sistem pemikiran ataupun kelas peristiwa yang terjadi di era milenial. Hal ini bertujuan untuk membuat deskripsi atau gambaran secara sistematis serta hubungan antar fenomena yang diselidiki. Bigdan dan Taylor dalam Moleong mengemukakan bahwa penelitian kualitatif adalah prosedur penelitian yang menghasilkan data deskriptif berupa kata-kata tertulis atau lisan dari orang-orang dan perilaku yang diamati. ${ }^{4}$ Penelitian kualitatif ini bertumpu pada latar belakang alamiah secara holistik dengan analisis data secara induktif untuk mendapatkan kesimpulan yang disepakati.

\footnotetext{
${ }^{4}$ Lexy J. Moleong, Metodologi Penelitian Kualitatif, (Bandung: PT. Remaja Rosdakarya, 2010), hlm 4.
} 


\section{HASIL DAN PEMBAHASAN}

\section{Problematika Sosial}

Problematika yang terjadi di masyarakat adalah perbedaan pendapat dalam menemukan jawaban tentang realitas hidup. Menurut Nurcholish Madjid, sebagaimana diketahui, Kitab Suci mengajarkan prinsip bahwa semua orang yang beriman adalah bersaudara, kemudian diperintahkan agar antara sesama orang beriman yang berselisih selalu diusahakan rujuk kembali dalam rangka taqwa kepada Allah dan usaha untuk mendapatkan rahmat-Nya. Pengajaran tentang persaudaraan itu kemudian langsung dilanjutkan dengan petunjuk tentang prinsip utama, yaitu bagaimana memelihara Ukhuwah Islamiyah (hubungan keselamatan dalam artian tali silaturahmi antarsesama). Prinsip utama dan pertama ini kemudian diteruskan dengan beberapa petunjuk yang lain untuk memperkuat dan mempertegas maknanya, dengan cara menjelaskan secara nyata mengenai hal-hal yang dapat merusak tali persaudaraan. Seperti saling meremehkan, sikap merendahkan orang lain atau kelompok lain dan selalu mencari kesalahan orang lain. Hal tersebut juga merupakan perwujudan inklusifitas dalam pelaksanaan dakwah terhadap kemajemukan yang sudah menjadi sunnatullah. ${ }^{5}$

Dari pengertian tersebut, maka ada kemungkinan diwujudkannya prinsip persaudaraan dan kemanusiaan yang benar, yang pada intinya setelah iman sebagai landasannya, selanjutnya ialah paham mengenai inklusifitas. Pertama, di antara sesama kaum beriman, berdasarkan prinsip kenisbian ke dalam (relatifisme internal). Menurut Ibn Taymiyyah, hal ini adalah "prinsip yang agung" (ashl 'adhim) yang harus dijaga dengan baik, sebagaimana yang telah diteladankan oleh Nabi Muhammad Saw. Kedua, di antara sesama umat manusia secara keseluruhan, paham kemajemukan dan menghargai perbedaan itu harus ditegakkan berdasarkan prinsip bahwa masing-masing kelompok manusia berhak untuk bereksistensi dan menempuh hidup sesuai dengan keyakinannya. ${ }^{6}$

Dewasa ini persoalan pemahaman tentang Islam seringkali kita temui dibentur-benturkan dengan kepentingan yang bersifat nisbi. Justru karena hal tersebut merupakan model yang paling pas yang bisa digunakan untuk mempengaruhi masyarakat awam. Agama dijadikan kendaraan politik identitas dengan melakukan pembunuhan karakter pada lawan politik. Atau menjadikan panggung agama sebagai pentas drama yang bertujuan untuk mendapatkan simpati sekelompok golongan yang menjadi sumber dukungan.

Ali Syari'ati menuliskan hal lain tentang persoalan manusia mengenai bagaimana seharusnya mengenal Islam. ${ }^{7}$ Menurutnya, memandang Islam harus melalui banyak

\footnotetext{
${ }^{5}$ Nurcholish Madjid, Islam Doktrin dan Peradaban,.....hal. xii

${ }^{6}$ Nurcholish Madjid, Islam Doktrin dan Peradaban,.....hal. xiii.

7 Syari'ati, Ali, "Islam Agama Protes", terjemahan Satrio Pinandito, Yogyakarta, Pribumi Publishing, 2017, hal. 104.
} 
pendekatan agar lebih banyak informasi untuk mengetahuinya bahkan mengamalkannya. Ia berpendapat bahwa semua orang tidak dapat melakukan pendekatan terhadap Islam hanya melalui satu pendekatan saja, karena Islam bukanlah agama yang didasarkan pada perasaanperasaan mistis manusia, atau hanya terbatas pada hubungan Tuhan dan manusia dan berhenti disitu.

Prof. Quraish Shihab dalam bukunya Washatiyah memaparkan bahwa orang-orang masa ini cenderung tidak melihat konteks dan situasi yang tepat dalam menafsirkan dan mengambil rujukan Al-Qur'an dan Hadits ketika menyampaikan dakwah (berdakwah), menurutnya, mereka tidak sadar bahwa sikap keras yang diperintahkan dalam ayat-ayat tertentu adalah berkaitan dengan sasaran tertentu yang dihadapi dan dialami pada masanya. Dalam hal ini juga perlu pemahaman tentang moderasi dalam beragama dan kemudian menjadi landasan berdakwah guna mewujudkan inklusifitas dalam dakwah. Hal tersebut diharapkan dapat mencegah munculnya pengaruh ekstremis kepada masyarakat yang tidak memahami persoalan-persoalan yang berkenaan dengan agama. ${ }^{8}$

Shihab melanjutkan, mencegah ekstremisme diperlukan diagnosis sebab-sebabnya dan untuk mengobatinya diperlukan penjelasan bijaksana tentang ajaran Islam yang disampaikan melalui ceramah dan dakwah Islam oleh juru dakwah, mengisi seseorang yang telah terisi dengan ide-ide yang keliru bukanlah perkara mudah, karena jauh lebih sulit daripada mengisik benak seseorang yang masih kosong. Menjelaskan ajaran Islam yang penuh kasih dan disampaikan dengan sikap yang menimbulkan simpati adalah salah satu cara yang tepat. Kerjasama semua pihak diperlukan sembari memberikan penjelasan sejak dini kepada generasi muda, melalui lembaga pendidikan dan keteladanan dalam rumah tangga, terutama dari keluarganya. ${ }^{9}$

Persoalan di masyarakat tentu begitu kompleks, menyebabkan kebanyakan dari mereka mengambil cara-cara yang mudah dan tidak mau berpikir dan menyaring terlebih dahulu apa yang disampaikan, benar dan salah, baik atau pun buruknya. Dakwah memegang peranan penting, agar masyarakat tidak perlu resah dihadapkan pada masalah yang tidak substansial. Penjelasan yang tepat dalam berdakwah dan memberikan keterangan yang seharusnya pada porsi yang pas adalah cara dan straegi khusus yang perlu dimiliki seorang juru dakwah. Mereka akan bertemu dan berkecimpung di masyarakat. Masyarakat akan menjadikan mereka sebagai rujukan dalam persoalan yang sebenarnya bisa diselesaikan lewat diri mereka sendiri bahkan.

8 Shihab, M. Quraish, "Wasathiyyah wawasan Islam tentang Moderasi Beragama", Ciputat, Lentera Hati, 2020, hal. Xii.

${ }_{9}^{9}$ Shihab, M. Quraish, “Wasathiyyah wawasan Islam... hal. 114-115. 
Jika Islam adalah cara menuju pada kebenaran mutlak yang ditujukan kepada Tuhan Yang maha Esa, maka tentulah ia tidak hanya mengajak semua manusia hanya melakukan ibadah rutinitas saja. Manusia seharusnya diberikan pemahaman bahwa mementingkan kehidupan manusia lain, membantu orang yang kesusahan dan mendedikasikan diri untuk kepentingan makhluk lain yang sejenis ialah bagian dari pengabdian diri kepada Tuhan Yang Maha Esa. Sehingga dengan pemahaman ini tentu kita tidak hanya menempatkan bahwa agama adalah sebuah entitas yang memproduksi orang-orang 'alim saja, orang-orang yang suci dalam pandangan dzahir, yang tampak mengenakan baju agama namun sebenarnya hal tersebut adalah sebuah topeng yang belum tau benar atau tidaknya apa yang ada di balik topeng tersebut.

Menjalankan sunnah juga merupakan perintah dalam agama, karena ia berisi penjabaran dari apa yang dituliskan dalam kitab suci. Sunnah menyentuh apa yang menjadi kenyataan yang tidak tertulis, dan itu juga perlu dipahami sebagai sebuah ibadah. Dasar sunnah dapat artikan sebagai tingkah laku dan contoh yang merupakan teladan. Menurut Fazlur Rahman, kepatuhan terhadap teladan itu sendiri bukanlah sebagian dari sunnah. Tetapi menjalankan sunnah sebagai kesadaran yang menjadi pendidikan akhlak yang bersumber dari Rasulullah Saw adalah sebuah hal yang perlu diperkokoh. ${ }^{10}$ Pemahaman inilah yang oleh kebanyakan orang merasa telah menjalankan sunnah yang diajarkan oleh Rasul, namun sebatas hanya apa yang tampak pada tampilan semata tanpa ada isi yang menyelimuti hati seorang muslim.

Memberikan teladan tentu adalah perbuatan yang baik, menyampaikan dakwah dan nasihat adalah salah satu sunnah yang baik. Para ahli etika berpendapat bahwa, kebaikan lebih mulia dari keadilan, bertolak belakang dengan apa yang dijelaskan oleh Ali bin Abi Thalib, menurutnya, dengan argumentasi tertentu, keadilan lebih tinggi daripada kebaikan. ${ }^{11}$ Haidar Bagir berpendapat, pada zaman ini penganut agama mengalami kemandegan (stagnansi) yang mengakibatkan mereka semua itu menganggap bahwa mereka hanya perlu berpegang teguh pada keyakinan yang simpel dan instant yang menjanjikan ketentraman hidup, janji keselamatan dunia dan akhirat. Oleh karena itulah terjadi sebuah konsep yang sempit sehingga orang-orang ini cenderung memilih keyakinan yang fundamentalistik karena dianggap itu yang paling tepat sebagai solusi dari persoalan keduniaan yang melelahkan. ${ }^{12}$

Hal tersebut lalu memacu orang-orang berlomba menginformasikan dan mengekspresikan diri mereka adalah yang paling benar sementara yang berada di luar garis hal. 2.

${ }^{10}$ Rahman, Fazlur, "Membuka Pintu Ijtihad", terjemahan Anas Mahyuddin, Bandung, Pustaka, 1995,

11 Muthahhari, Murtadha, "Islam Agama Keadilan", terjemahan Agus Effendi, Jakarta, Pustaka Hidayah, 1988, hal. 30.

12 Bagir, Haidar,"Islam Tuhan Islam Manusia Agama dan Spriritualitas di Zaman Kacau, Bandung, Mizan, 2019, hal. 43-44. 
dan barisan mereka adalah orang yang perlu diperangi, ini apa yang disebut sebagai akar radikalisme. Paham inilah sebetulnya yang menjadi alasan utama mengapa dakwah yang dilakukan oleh seorang juru dakwah perlu mengedepankan aspek inklusifitas dan haluan yang humanis. Dengan tujuannya orang-orang tidak perlu merasa diri mereka lebih baik sementara orang lain bersalah dan berdosa sehingga harus dihakimi.

\section{Inklusifitas Pelaksanaan Dakwah Islam}

Meninggalkan sifat rakus dan serakah, saling menindas dan memfitnah dan meninggalkan tindakan yang merusak dunia ini merupakan sebuah keniscayaan yang harus kita lakukan dalam rangka menjadi bagian masyarakat dunia yang luas. Tanpa adanya dakwah, manusia akan kehilangan cinta kasih, rasa keadilan dan nurani sebagai seorang makhluk, kepedulian sosial dan lingkungan serta tidak perdulia akan sesamanya. ${ }^{13}$

Menurut Ahmad dan Khaerunnisa dalam tulisannya, Inklusif berasal dari bahasa Inggris Inclusive yang merupakan kata sifat bermakna including everything yang artinya "termasuk semuanya". Inklusif yang dimaksudkan ini adalah dalam hal pemahaman teologi. Teologi inklusif adalah pengembangan paham dan kehidupan keagamaan yang memperlihatkan keluwesan, toleran, dan respek terhadap inklusifitas dalam keagamaan, sehingga para penganut berbagai aliran keagamaan atau agama-agama dapat hidup berdampingan secara damai. Dalam konteks agama Islam, term inklusif lebih dekat diasosiasikan sebagai Islam yang cenderung kontekstual. ${ }^{14}$

Pendapat lain disampaikan oleh Bambang Saiful Ma'arif, 15 ia menyampaikan bahwa dakwah inklusif penting diartikan sebagai memandang dakwah Islam sebagai menekankan pada kesamaan dan menjauhkan perbedaan, sehingga muncul istilah "Indahnya Kebersamaan". Masyarakat Muslim merupakan satu kesatuan, yang tidak bisa dipecah-belah. Persamaan diutamakan, sehingga umat Islam dapat bekerja sama, yang akan memperkuat kerjasama di kalangan kaum Muslimin. Oleh karena itulah mengapa inklusifitas dalam dakwah diperlukan dengan harapan tidak ada perbedaan dalam pandangan dakwah. Menyampaikan sesgala sesuatu dengan mengutamakan indahnya kebersamaan, guna meninggalkan kesan yang membangun dan damai serta mampu diterima oleh masyarakat.

Aktivitas dakwah menjadi tugas seluruh umat, tidak hanya monopoli kelompok yang disebut ulama maupun cendekiawan. Dalam melakukan aktivitas dakwah, da'i atau pelaku hal. xiii.

${ }^{13}$ Ismail, Nawari, Filsafat Dakwah (Ilmu Dakwah dan Penerapannya), (Jakarta: PT Bulan Bintang 2004),

14 Ahmad Hidayatullah dan Khaerunnisa Tri Darmaningrum, "Inklusifitas Dakwah Akun @Nugarislucu Di Media Sosial", Islamic Communication Journal, Vol. 4, No. 2, 2019. hal. 185.

${ }_{15}$ Bambang Saiful Ma'arif, "Dimensi Inklusi Dakwah KH. Abdullah Gymnastiar dan KH. Jalaluddin Rakhmat ", Mimbar, Vol. XXVII, No. 1 2011, hal. 41. 
dakwah dituntut untuk melakukan dakwah secara santun, beradab dan juga hikmah atau bijkasana. Dalam konteks Indonesia yang sangat kental dengan pluralisme, tentunya hikmah menjadi hal yang sangat penting dan strategis. Dengan hikmah inilah maka dapat dirumuskan sebuah konsep dakwah yang inklusif. Dakwah inklusif adalah dakwah yang menekankan pada kesamaan dan menjauhkan dari perbedaan sehingga muncul anggapan bahwa dalam kehidupan ini kita semua sama. Adanya konsep dakwah inklusif menjadi mediator yang efektif untuk menyatukan umat yang mulai terpecah belah akibat masih adanya sikap ekslusivitas dalam beragama. ${ }^{16}$

Upaya untuk mengikis eksklusivitas yang mulai menjamur di masyarakat merupakan strategi untuk menghidupkan kembali inklusivitas yang mulai redam. Dalam masyarakat plural, dibutuhkan pemikiran dan sikap inklusif yang menekankan keterbukaan bahwa di luar kebenaran agama yang dianut juga terdapat kebenaran agama yang lain meskipun tidak sesempurna dan seutuh agama yang dianutnya. ${ }^{17}$ Pemahaman seperti ini haruslah ditumbuhkan pada masyarakat kita, mengingat pandangan inklusif bukanlah sebuah pandangan atau doktrin yang bertentangan dengan agama. Karena secara sadar, masyarakat akan memiliki sikap toleran dan bersahabat dengan penganut agama yang lain tanpa mengedepankan kebenaran masing-masing agama. Dengan demikian, sikap inklusif perlu digerakkan oleh bangsa Indonesia agar kerukunan antarumat dan antarbangsa dapat tercipta dengan baik.

Menampilkan wacana inklusif dalam islam sebagai bentuk tindakan kongkrit untuk menjawab problematika kehidupan beragama. ${ }^{18}$ Islam secara tegas menghendaki suatu sistem yang menguntungkan semua orang termasuk mereka yang bukan islam. Adanya perbedaan agama tidak dilihat sebagai faktor pemisah maupun pemicu konflik, karena masing-masing agama akan mempertimbangkan kebenarannya sesuai pemahaman masing-masing. Pandangan inklusif pada aspek agama ini dapat memberi dimensi baru dalam kehidupan sosial. Keadaan ini sangat efektif diterapkan kepada masyarakat majemuk sebagai jembatan dalam menghadapi perbedaan sekaligus menyerukan dialog yang humanis yaitu sama-sama sebagai makhluk Allah SWT.

Pemahaman inklusifitas ini tidak secara langsung dipahami sebagai pengakuan kebenaran atas semua agama yang ada. Melainkan sebuah sikap beragama yang terbuka (open religion) untuk menyadari kemajemukan keagamaan yang pada mulanya menganut prinsip

\footnotetext{
${ }^{16}$ Luluk Fikri Zuhriyah, Dakwah Inklusif Nurcholis Madjid, Jurnal komunikasi Islam Vol 02, No 02.

17 Yusria Ningsih dan Ulul Aflika, Dakwah di Tengah Heterogenitas Masyarakat dan Perbedaan Umat, Proceedings of International Conference On Da'wah and Communication, Vol 1 No 12019.

18 Bambang Saiful Ma'arif, Dimensi Inklusi Dakwah KH.Abdullah Gymnastiar dan KH.Jalaluddin Rakhmat, Jurnal Mimbar, Vol XXVII, No. 1 Juni
} 
yang sama, yaitu keharusan untuk berserah diri kepada Yang Maha Esa sesuai dinamika internal masing-masing agama. Nucholis Madjid sebagai promotor dalam menyuarakan inklusivitas dakwah seringkali menegaskan bahwa islam merupakan agama yang terbuka dan umat islam harus menjadi golongan yang terbuka. ${ }^{19}$ Artinya disini adalah islam selalu memberikan tempat yang tinggi terhadap ide pertumbuhan dan perkembangan, yaitu pemahaman tentang ruang gerak agama yang dinamis.

Dari ungkapan di atas, sangat jelas bahwa inklusivitas beragama menjadi sebuah sikap positif-optimis untuk menghadapi kemajemukan. Apabila pemahaman ini dikembangkan secara konsisten, maka implikasi yang terlihat adalah keadaan yang harmonis bahwa manusia dapat menghormati dan menghargai perbedaan manusia yang lainnya. Hal ini sebagaimana tertulis dalam QS. Al-Hujurat ayat 11:

"Wahai orang-orang yang beriman! Janganlah suatu kaum mengolok-olok kaum yang lain, (karena) boleh jadi mereka (yang diperolok-olok) lebih baik dari mereka (yang mengolok-olok), dan jangan pula perempuan-perempuan (mengolok-olok) perempuan yang lain, (karena) boleh jadi perempuan (yang diperolok-olok) lebih baik dari perempuan (yang mengolok-olok)."

Menumbukan konsistensi inklusivitas dalam permasalahan keagamaan maupun sosial akan memunculkan sikap toleransi untuk menerima perbedaan pemahaman yang ada. ${ }^{20}$ Relativisme internal ini tidak akan menghilangkan kebenaran agama yang dianut oleh orang lain, melainkan dapat menghidupkan semangat mencari kebenaran yang lapang dan terbuka tanpa mengedepankan eksklusivitas atau fanatisme beragama sebagai pemicu awal konflik internal.

Sikap inklusivitas dapat memicu berkembangnya sikap-sikap pluralis. Adanya pengaruh globalisasi menjadikan masyarakat sangat transparan satu dan yang lain. Masyarakat yang hidup dalam dunia global, harus senantiasa memegang prinsip inklusif dengan cara menyebarkan visi yang religius, adil, terbuka dalam menyikapi perbedaan antar berbagai kelompok. Adanya kemudahan yang dapat dirasakan di era global ini tentu menjadi peluang sekaligus ancaman yang dapat digunakan untuk membentuk perselisihan antarumat maupun antar golongan. Karena itu, penting untuk menanamkan konsep inklusivitas dengan cara melakukan dialog yang terus menerus antar berbagai kepercayaan demi mewujudkan atmosfir keberagamaan yang harmonis.

Spirit inklusivitas perlu untuk diterapkan dalam skala kehidupan global seperti politik, ekonomi, sosial, maupun budaya. Upaya ini dapat terwujud jika dilandasi dengan pondasi

19 Dede Ari Sopandi dan Mohamad Taofan, Konsep Teologi Inklusif Nurcholish Madjid, JAQFL: Jurnal Aqidah dan Filsafat Islam, Vol 4, No.2, 2019.

20 Zainal Abidin, Teologi Inklusif Nurcholish Madjid: Harmonisasi Antara Keislaman, Keindonesiaan, dan Kemoderenan, Jurnal Humaniora Vol 5 No 2. 
agama dan niat yang tulus. Semangat inklusifitas menjadi daya perekat yang kuat untuk menjalin kerjasama antar masyarakat majemuk. Hal ini sekaligus memberi ruang hubungan yang baik dengan kelompok-kelompok penganut agama lain untuk senantiasa mewujudkan fitrah manusia yang memiliki kecenderungan pada keadilan yang beradab. Keadilan disini bersifat seimbang kepada sesama manusia sehingga melahirkan keadaan positif bagi prinsip pluralisme sosial. Upaya ini tentunya dapat menjadi signifikansi inklusifitas dalam konteks keberagamaan yang pluralistik. ${ }^{21}$

Basis inklusivitas yang mampu menyentuh dan merangkul semua lapisan masyarakat Indonesia dapat membawa pesan-pesan islam pada tataran publik. Islam harus ditransformasikan ke dalam pemahaman yang objektif agar dapat diterima oleh seluruh lapisan masyarakat. Pesan-pesan inklusivitas dapat dimanifestasikan ke dalam konsep keadilan, kebebasan mengutarakan pendapat, persamaan hak antar manusia serta menunjung tinggi egalitarianisme dalam wujud toleransi. Dengan demikian, konsep inklusivitas akan mudah memasuki status epistemis yang dapat diterima oleh semua warga negara yang berbeda tanpa menimbulkan polemik yang berkepanjangan.

Dalam masyarakat kohesif yang terbingkai oleh keragaman budaya dan agama, inklusivitas harus terus menjadi orientasi dalam kehidupan sosial. Perwujudan keragaman dalam kehidupan sosial dapat dilakukan dengan mengedepankan pemahaman sosial keagamaan masyarakat. Dalam hal ini, peran dai atau komunikator dakwah menjadi faktor penting untuk mendekonstruksi pemahaman masyarakat yang cenderung eksklusif, dogmatis, maupun tidak menyentuh aspek moralitas. Da'i atau komunikator dakwah paling tidak memegang tiga fungsi utama dalam kehidupan sosial masyarakat, yaitu sebagai 1) motivator, 2) mediator, 3) pembimbing moral. ${ }^{22}$

Adanya tiga fungsi di atas, menjadikan da'i atau pelaku dakwah memiliki potensi yang besar untuk menciptakan harmonisasi sosial melalui model dakwah inklusif yang memupuk persaudaraan, menghargai perbedaan, menekankan kebaikan, serta kedamaian dan kemajemukan. Hal ini menjadi cara efektif untuk menangkal gerakan kontra keragaman yang menjadikan isu eksklusifitas sebagai strategi untuk memecah belah umat, padahal sejatinya masyarakat harus senantiasa paham tentang adanya misi agama yang damai bagi semua dan sesama. Atas dasar inilah, penguatan inklusivitas dalam berbagai aspek kehidupan harus selalu

21 Zaprulkhan, Signifikansi dakwah Inklusif Nurcholis Madjid Bagi Masyarakat Indonesia, Mawa'izh: Jurnal Dakwah dan Pengembangan Sosial Kemanusiaa, E-ISSN: 2614-5821 Vol 1, No 7, Juni 2016.

22 Muhammad Alifuddin, Dakwah Inklusif Dalam Masyarakat Segregatif di Aoma Dan Ambesakoa Sulawesi Tenggara, Jurnal Dakwah, Vol XVI, No 2. 
menjadi titik fokus guna membentuk kesadaran umat dalam beragama sekaligus sebagai basis kongkrit dalam menjawab segala problematika sosial yang ada.

\section{KESIMPULAN}

Sudah bukan rahasia lagi bahwa paham-paham keagamaan yang ada saat ini ada yang berhaluan garis keras. Mereka tidak segan mengatakan kata-kata kasar. Para penceramahnya tidak segan mengkafirkan sesama. Menafsirkan Al-Qur'an dan Hadits tanpa melalui kaidah tafsir yang benar dan tepat seperti ulama-ulama terdahulu. Menyebabkan para masyarakat awam mengikuti jalan pemikiran yang berlawanan dengan yang seharusnya disampaikan. Padahal isu kemanusiaan adalah hal yang menjadi keharusan yang menyadarkan kita semua bahwa diatas kepentingan kita dengan Tuhan Yang Maha Esa, kita diperintahkan untuk berbuat baik sesama manusia seperti yang diajarkan oleh Rasulullah Saw dulu. Tidak saja dengan sesama kita, melainkan pula dengan orang yang berbeda keyakinan sekalipun dalam konteks negara dan agama.

Dari pemaparan mengenai problematika sosial di atas dan juga inklusifitas dalam pelaksanaan dakwah Islam. Dapat ditarik dua kesimpulan, yaitu; Pertama, bahwa permasalahan kehidupan sosial di masyarakat terkait perbedaan dalam memaknai agama menjadi hal yang tidak bisa disepelekan. Hal tersebut justru harus diurai secara komprehensif. Apapun yang menjadi pertentangan dalam menjalankan ibadah sehari-hari, perlu ada kontrol dari pelaku dakwah. Peranan pelaku dakwah inilah yang menjadi target dalam pemersatu masyarakat. Kedua, inklusifitas dakwah memang bukanlah hal baru di era modernisasi saat ini. Ia telah lama ada dan mengiringi kehidupan setiap muslim. Tetapi, dengan berbagai persoalan yang terjadi, ragam paham yang kini hadir seakan mulai mengubur eksistensi inklusifitas dakwah ini menjadi eksklusifitas. Sebagaimana telah dijelaskan bahwa inklusifitas dakwah yang ada dalam ruang publik ialah memberikan peluang kepada manusia untuk menerima segala sesuatu dengan cara pandang yang positif, agar tidak menimbulkan permasalahan yang dikhawatirkan.

\section{REFERENSI}

Bagir, Haidar,"Islam Tuhan Islam Manusia Agama dan Spriritualitas di Zaman Kacau, Bandung, Mizan, 2019.

Bambang Saiful Ma'arif, "Dimensi Inklusi Dakwah KH. Abdullah Gymnastiar dan KH. Jalaluddin Rakhmat “, Mimbar, Vol. XXVII, No. 1 (Juni 2011).

Bambang Saiful Ma'arif, Dimensi Inklusi Dakwah KH. Abdullah Gymnastiar dan KH. Jalaluddin Rakhmat, Jurnal Mimbar, Vol XXVII, No. 1 Juni 
Dede Ari Sopandi dan Mohamad Taofan, Konsep Teologi Inklusif Nurcholish Madjid, JAQFL: Jurnal Aqidah dan Filsafat Islam, Vol 4, No. 2, 2019

Fitria, Rini dan Rafinita Aditia, Prospek dan Tantangan Dakwah Bil Qalam sebagai Metode Komunikasi, Jurnal Ilmiah Syi'ar Vol. 19 No. 02, 2019.

Hidayatullah, Ahmad dan Khaerunnisa Tri Darmaningrum, "Inklusifitas Dakwah Akun @Nugarislucu Di Media Sosial", Islamic Communication Journal Volume 4, Nomor 2, JuliDesember 2019.

Ismail, Nawari, Filsafat Dakwah (Ilmu Dakwah dan Penerapannya), PT Bulan Bintang, Jakarta, 2004. Lexy J. Moleong, Metodologi Penelitian Kualitatif, (Bandung: PT. Remaja Rosdakarya, 2010).

Luluk Fikri Zuhriyah, Dakwah Inklusif Nurcholis Madjid, Jurnal komunikasi Islam ISSBN 20886314 Vol 02, No 02 Desember

Mubarak, M. Zaki. 2008. Generalogi Islam Radikal di Indonesia (Gerakan, Pemikiran dan Prospek Demokrasi). Jakarta: LP3ES.

Muhammad Alifuddin, Dakwah Inklusif Dalam Masyarakat Segregatif di Aoma Dan Ambesakoa Sulawesi Tenggara, Jurnal Dakwah, Vol XVI, No 2.

Muhammad, Husein. 2011. Mengaji Pluralisme Kepada Maha Guru Pencerahan. Bandung: Mizan.

Muthahhari, Murtadha, "Islam Agama Keadilan", terjemahan Agus Effendi, Jakarta, Pustaka Hidayah, 1988.

Nafis, M. Wahyuni. 2014. Cak Nur Sang Guru Bangsa. Jakarta: Kompas.

Ningsih, Yusria dan Ulul Aflika, Dakwah di Tengah Heterogenitas Masyarakat dan Perbedaan Umat, Proceedings of International Conference On Da'wah and Communication, Vol 1 No 1 2019.

Qodir, Abdul. 2004. Jejak Langkah Pembaruan Pemikiran Islam di Indonesia. Bandung: CV Pustaka Setia.

Qodir, Zuly. 2009. Gerakan Sosial Islam: Manifesto Kaum Beriman. Yogyakarta: Pustaka Pelajar.

Rachman, Budhy Munawar. 2006. Ensiklopedi Nurcholish Madjid. Jakarta: Mizan.

Rahman, Fazlur, "Membuka Pintu Ijtihad", terjemahan Anas Mahyuddin, Bandung, Pustaka, 1995.

Ramayulis. 2006. Psikologi Agama. Jakarta: Kalam Mulia.

Ramdhani, Rahmat . Dakwah dan Pemberdayaan Masyarakat Berbasis Agama, Jurnal Syi'ar Vol. 18 No. 2 Juli-Desember 2018.

Saridjo, Marwan, 2005. Cak Nur: Di Antara Sarung dan Dasi \& Musdah Mulia Tetap Berjilbab. Cet. II . Jakarta: Yayasan Ngali Aksara.

Shihab, Alwi. 1999. Islam Inklusif: Menuju Sikap Terbuka dalam Beragama. Cet. VII. Bandung: Mizan. 
Shihab, M. Quraish, "Wasathiyyah wawasan Islam tentang Moderasi Beragama", Ciputat, Lentera Hati, 2020.

Shofan , Moh. dan Ali Usman (ed). 2008. Esai-esai Pemikiran Moh. Shofan dan Refleksi Kritis Kaum Pluralis Menegakkan Pluralisme, Fundamentalisme-Konservatif di Tubuh Muhammadiyah. Yogjakarta: Ar-Ruzz Media.

Sofyan, Ahmad A. dan Roychan Madjid. 2003. Gagasan Cak Nur Tentang Negara dan Islam. Yogyakarta: Titian Ilahi Press.

Sulthon Muhammad, Desain Ilmu Dakwah, Jakarta: Pustaka Pelajar, 2003.

Sumbulah, Umi. 2010. Islam Radikal dan Pluralisme Agama: Studi Konstruksi Sosial Aktivis Hizb al Tahrir dan Majelis Mujahidin di Malang tentang Agama Kristen dan Yahudi. Jakarta: Balitbang dan Diklat Kemenag RI.

Syari'ati, Ali, "Islam Agama Protes", terjemahan Satrio Pinandito, Yogyakarta, Pribumi Publishing, 2017.

Thaha, Idris. 2005. Demokrasi Religius: Pemikiran Politik Nurcholish Madjid dan M. Amien Rais. Jakarta: Teraju.

Usman, Ali. 2008. Menegakkan Pluralisme. Jakarta: LSAF \& Ar-Ruzz Media.

Wahib, Ahmad. 1993. Pergolakan Pemikiran Islam: Catatan Harian Ahmad Wahib. Jakarta: LP3ES.

Woodward, Mark R. (ed). 1999. Jalan Baru Islam Memetakan Paradigma Mutakhir Islam Indonesia. Bandung: Mizan (Terjemahan dari Toward A New Paradigm : Recent Development in Indonesian Islamic Thought, terbitan Arizona State University 1996).

Zainal Abidin, Teologi Inklusif Nurcholish Madjid: Harmonisasi Antara Keislaman, Keindonesiaan, dan Kemoderenan, Jurnal Humaniora Vol 5 No 2 Oktober

Zaprulkhan, Signifikansi dakwah Inklusif Nurcholis Madjid Bagi Masyarakat Indonesia, Mawa'izh: Jurnal Dakwah dan Pengembangan Sosial Kemanusiaa, E-ISSN: 2614-5821 Vol 1, No 7, Juni 2016 